\title{
Lead Isotope Characterization of Petroleum Fuels in Taipei, Taiwan
}

\section{Pei-Hsuan Yao ${ }^{1}$, Guey-Shin Shyu ${ }^{2}$, Ying-Fang Chang ${ }^{3}$, Yu-Chen Chou ${ }^{4}$, Chuan-Chou Shen ${ }^{4}$, Chi-Su Chou ${ }^{5}$ and Tsun-Kuo Chang ${ }^{1, *}$}

1 Agro-environment Laboratory (AELab), Department of Bioenvironmental Systems Engineering, National Taiwan University, Taipei City 106, Taiwan; E-Mail: d97622006@ntu.edu.tw (P.-H.Y.) Department of Travel and Ecotourism, Tungnan University, New Taipei City 222, Taiwan; E-Mail: gsshyu@mail.tnu.edu.tw

3 Green Energy and Environment Research Laboratories, Industrial Technology Research Institute, Hsinchu County 310, Taiwan; E-Mail: changyingfang@itri.org.tw

4 High-Precision Mass Spectrometry and Environmental Change Laboratory (HISPEC), Department of Geosciences, National Taiwan University, Taipei City 106, Taiwan; E-Mails: r99224105@ntu.edu.tw (Y.-C.C.); river@ntu.edu.tw (C.-C.S.)

5 Ecological Engineering Research Center, National Taiwan University, Taipei City 106, Taiwan; E-Mail: chisuchou2012@gmail.com

* Author to whom correspondence should be addressed; E-Mail: tknchang@ntu.edu.tw; Tel.: +886-2-3366-3466; Fax: +886-2-2363-1879.

Academic Editor: Howard W. Mielke

Received: 14 March 2015 / Accepted: 20 April 2015 / Published: 24 April 2015

\begin{abstract}
Leaded gasoline in Taiwan was gradually phased out from 1983 to 2000. However, it is unclear whether unleaded gasoline still contributes to atmospheric lead $(\mathrm{Pb})$ exposure in urban areas. In this study, $\mathrm{Pb}$ isotopic compositions of unleaded gasolines, with octane numbers of 92, 95, 98, and diesel from two local suppliers in Taipei were determined by multi-collector inductively coupled plasma mass spectrometry with a two-sigma uncertainty of $\pm 0.02 \%$. Lead isotopic ratios of vehicle exhaust $\left({ }^{208} \mathrm{~Pb} /{ }^{207} \mathrm{~Pb}: 2.427\right.$, ${ }^{206} \mathrm{~Pb} /{ }^{207} \mathrm{~Pb}$ : 1.148 , as estimated from petroleum fuels) overlap with the reported aerosol data. This agreement indicates that local unleaded petroleum fuels, containing $10-45 \mathrm{ng} \cdot \mathrm{Pb} \cdot \mathrm{g}^{-1}$, are merely one contributor among various sources to urban aerosol $\mathrm{Pb}$. Additionally, the distinction between the products of the two companies is statistically
\end{abstract}


significant in their individual ${ }^{208} \mathrm{~Pb} /{ }^{206} \mathrm{~Pb}$ ratios $(p$-value $<0.001, \mathrm{t}$ test). Lead isotopic characterization appears to be applicable as a "fingerprinting" tool for tracing the sources of $\mathrm{Pb}$ pollution.

Keywords: stable lead isotopes; environmental forensics; petroleum fuels

\section{Introduction}

Lead $(\mathrm{Pb})$ is a toxic but useful element for human and has four stable isotopes, ${ }^{204} \mathrm{~Pb},{ }^{206} \mathrm{~Pb},{ }^{207} \mathrm{~Pb}$, and ${ }^{208} \mathrm{~Pb}$. Besides the largest use of $\mathrm{Pb}$ for lead-acid batteries, it is also used in alloys, as an anti-knock additive in petrol, cables, chemicals, solders, etc. [1]. Leaded gasoline, with alkyllead compounds as antiknock additives, was a major source of human $\mathrm{Pb}$ exposure and environmental $\mathrm{Pb}$ pollution through the 1980s [1-3]. Developing countries have set up strict regulations to ban $\mathrm{Pb}$ additives, e.g., tetraethyl and tetramethyl $\mathrm{Pb}$, in order to eliminate the release of $\mathrm{Pb}$ from gasoline combustion $[1,3,4]$. Lead isotopic signatures have been demonstrated to be reliable tracers for distinguishing different sources of local and global $\mathrm{Pb}$ pollution (e.g., Erel et al. [5], Keinonen [6], Monna et al. [7], Mukai et al. [8], Widory et al. [9], Zheng et al. [10]). Atmospheric $\mathrm{Pb}$ has various origins in addition to the natural background such as coal and gasoline combustion, industrial emissions, lead smelters, and waste incineration [7,9,11]. Isotopic techniques have been used on $\mathrm{Pb}$ related environmental studies. For example, Monna et al. [7] utilized $\mathrm{Pb}$ isotopes to conduct environmental forensic studies in France and UK. Their results revealed gasoline was the main source of $\mathrm{Pb}$ in airborne particulate matter in France and UK. Widory et al. [9] coupled $\mathrm{Pb}$ and $\mathrm{Sr}$ isotopes to characterize the origin of aerosols in Beijing, China, and $\mathrm{Pb}$ isotopic ratios suggested that metal refining plants were the major source of atmospheric $\mathrm{Pb}$, followed by thermal power stations and other coal combustion process.

The phasing out of $\mathrm{Pb}$ in gasoline in Taiwan started in 1983. In 2000, the supply of leaded gasoline was officially discontinued. Unleaded gasoline, containing less than $0.0013 \mathrm{~g} / \mathrm{L}$ of $\mathrm{Pb}$, was introduced [12]. Chinese Petroleum Corporation, Taiwan (CPC) and Formosa Plastics Corporation (FPC) are the major supplier of petroleum fuels in Taiwan [13]. Taiwan relies heavily on imported crude oil which accounts for $99 \%$ of nation's crude oil needs. Taiwan's petroleum products follow a simplified process of crude oil unloading, refining, blending, transportation, and filling at service stations. By the end of 2012, 2668 gas stations were in service [14]. Also, more than 22.3 million on-road vehicles were operated in Taiwan, a number that almost doubled in the last two decades [14]. Atmospheric $\mathrm{Pb}$ concentrations in Taipei declined from $700 \mathrm{ng} / \mathrm{m}^{3}$ in 1991 [15] to $34 \mathrm{ng} / \mathrm{m}^{3}$ in 2002-2003 [16] and $27 \mathrm{ng} / \mathrm{m}^{3}$ in 2003-2004 [17]. Cord blood Pb levels decreased from $74.8 \pm 22.5 \mu \mathrm{g} / \mathrm{L}$ in 1985-1987 [18] to $12.6 \pm 1.8 \mu \mathrm{g} / \mathrm{L}$ in 2004-2005 [19]. These monitoring results indicate that the human exposure to environmental $\mathrm{Pb}$ in Taiwan has declined since the use of unleaded gasoline.

Hsu et al. [16] suggested that high level of atmospheric $\mathrm{Pb}$ in Taipei city, Taiwan might have occurred during the winter, under the influence of the northeast monsoon. They also demonstrated the impact of dust from China through the analysis of air mass trajectory and seasonal variations of $\mathrm{Pb}$ isotopic ratios in Taipei aerosols [17]. However, only particulate samples from the main tunnels in Taipei have been compared, and there was no direct data from fuel products or vehicle exhaust analysis. 
In another study, $\mathrm{Pb}$ isotopic ratios of aerosols in Pengjia Islet, where fuel combustion was negligible, have shown seasonal variations [20], but the $\mathrm{Pb}$ origins were not clear.

Since no isotopic fractionation occurs during any refining process, $\mathrm{Pb}$ isotopic characteristics are specific and unchanged for a given crude oil, fuel additive, gasoline, or $\mathrm{Pb}$ ore [21]. Although $\mathrm{Pb}$ from fuel combustion has been considered as a contributor to urban atmosphere in previous studies, direct $\mathrm{Pb}$ isotopic ratios survey in petroleum fuel is still rare. Until now, only $\mathrm{Pb}$ isotopic determination in unleaded gasoline products of Israel [4] and USA [21] has already been reported, whereas Pb isotopes in petroleum products of Taiwan has never been reported. The purposes of this study were, first of all, to determine $\mathrm{Pb}$ isotopic signatures of local fuel products, and secondly, to compare these signatures with those of other potential sources of atmospheric $\mathrm{Pb}$, through data obtained in an urban area and from an islet with negligible fuel combustion.

\section{Materials and Methods}

\subsection{Sampling}

In recent years, unleaded gasoline, \#92, \#95, \#98, and diesel from Chinese Petroleum Corporation, Taiwan (CPC) and Formosa Plastics Corporation (FPC) are commercially available in Taiwan [13]. The two suppliers use different dyestuffs for products identification. The color of $\# 92$ unleaded gasoline is green, while \#95, \#98 and diesel from CPC are yellow, red and yellow, respectively. FPC's products are blue (\#92), light yellow (\#95), red (\#98), and yellow (diesel). Fuel products were collected from service stations in metropolitan Taipei in 2012 (modified from Monna et al. [7]). After cleaning the gas pump nozzle dispenser with Kimwipes, each fuel sample was directly filled into an acid-clean $250 \mathrm{~mL}$ Teflon bottle and stored before chemical analysis.

\subsection{Chemistry}

Water was purified using a tandem ultrapure water system with Millipore Milli-Q ACADEMIC and Milli-Q ELEMENT systems. Teflon labware was acid-cleaned. All reagents were of ultrapure grade. Chemical procedure and instrumental analyses were performed on benches with class-100 laminar-flow air in a class-10000 clean room (Shen et al. [22]).

Sample treatment was done according to the following modified Monna's method [7]. Gasoline sample ( $30 \mathrm{~g} ; 0.3 \mathrm{~g}$ for diesel) was kept in a $30 \mathrm{~mL}$ Teflon vial and slowly evaporated at elevated temperature up to $150{ }^{\circ} \mathrm{C}$ on a hotplate for $5 \mathrm{~h}$. The residue was digested with $2 \mathrm{~mL} 14 \mathrm{~N} \mathrm{HNO}_{3}$ and

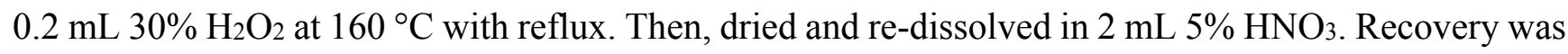
$99.8 \%-103.7 \%$. The solution was separated into two aliquots $(\mathrm{w} / \mathrm{w}=1: 3)$, one for detecting $\mathrm{Pb}$ content and the other for further $\mathrm{Pb}$ separation and isotopic determination. Lead separation process was conducted with Eichrom 100-150-mesh Sr-Spec resin using the method modified from Gale [23]. Overall procedural $\mathrm{Pb}$ blank was $20 \mathrm{pg}$. Lead mass loss was $<10 \%$.

Lead concentration was determined by a calibration plot, established with Merck Multi-Element Standards, on an inductively-coupled plasma-sector field mass spectrometer (ICP-SF-MS), Element II, Thermo Fisher (Bremen, Germany), with a detection limit of $0.001 \mathrm{ppb}$. The relative percent differences (RPD) were $<7 \%$. Lead isotopic ratios were determined by a multi-collector ICP-MS (MC-ICP-MS; 
Neptune, Thermo Fisher), equipped with a dry introduction device (Cetac Aridus, Teledyne CETAC Technologies, NE, USA). Three isobaric interferences, ${ }^{204} \mathrm{Hg}$, WO and ReO, were reported [24]. The intensities of ion beams of $\mathrm{WO}^{+}$and $\mathrm{ReO}^{+}$can be eliminated through chromatographic separation. An isobaric interference of ${ }^{204} \mathrm{Hg}$ was only 1000 counts per second (cps), considered as insignificant. Thallium (Tl) isotopes were adopted for mass fractionation correction [24-27]. Lead isotopic ratios were normalized to ${ }^{205} \mathrm{Tl} /{ }^{203} \mathrm{Tl}=2.3889$ exponentially [24,28]. Replicate measurements made with 2-10 ng Pb for an international standard NIST SRM 981 showed the 2-sigma reproducibility of $\pm 0.02 \%$ (Table 1).

Table 1. Comparisons of precision and accuracy (NIST SRM 981; mean \pm 2 S.D.).

\begin{tabular}{ccccc}
\hline Reference & ${ }^{208} \mathbf{P b} /{ }^{206} \mathbf{P b}$ & ${ }^{207} \mathbf{P b} /{ }^{\mathbf{2 0}} \mathbf{P b}$ & ${ }^{206} \mathbf{P b} /{ }^{\mathbf{0 4}} \mathbf{P b}$ & Method \\
\hline Baker [24] & $2.1678 \pm 0.0001$ & $0.9149 \pm 0.0004$ & $16.942 \pm 0.001$ & DS, MC-ICP-MS \\
& $2.1678 \pm 0.0002$ & $0.9149 \pm 0.0004$ & $16.94 \pm 0.01$ & Tl, MC-ICP-MS \\
\hline Galer and Abouchami [29] & $2.1677 \pm 0.0001$ & $0.91475 \pm 0.00004$ & $16.941 \pm 0.001$ & TS, TIMS \\
\hline Thirlwall [30] & $2.1677 \pm 0.0002$ & $0.91483 \pm 0.00006$ & $16.941 \pm 0.001$ & DS, TIMS \\
\hline Thirlwall [28] & $2.1677 \pm 0.0002$ & $0.91488 \pm 0.00008$ & $16.942 \pm 0.003$ & DS, MC-ICP-MS \\
\hline Weiss et al. $[26]$ & $2.1677 \pm 0.0006$ & 0.91404 & $16.947 \pm 0.008$ & Tl, MC-ICP-MS \\
\hline White et al. [27] & $2.1646 \pm 0.0008$ & $0.9148 \pm 0.0001$ & $16.941 \pm 0.004$ & Tl, MC-ICP-MS \\
\hline This study & $2.1675 \pm 0.0003$ & $0.9148 \pm 0.0001$ & $16.941 \pm 0.008$ & Tl, MC-ICP-MS \\
\hline
\end{tabular}

DS: ${ }^{204} \mathrm{~Pb}^{2207} \mathrm{~Pb}$ double spike, $\mathrm{Tl}$ : $\mathrm{Tl}$ correction, $\mathrm{TS}:{ }^{204} \mathrm{~Pb}^{206} \mathrm{~Pb}^{207} \mathrm{~Pb}$ triple spike, MC-ICP-MS: multi-collector ICP-MS, TIMS: thermal ionization mass spectrometry.

\subsection{Environmental Impact}

Acids are toxic, corrosive reagents that can burn skin and damage respiratory organs. Therefore, waste acid was neutralized before discharge. Unused fuel products were recycled.

\section{Results}

\subsection{Lead Level of Taiwan's Fuel Products}

Results of $\mathrm{Pb}$ isotopic ratios and concentrations for Taiwan's fuel products are summarized in Table 2. Lead concentrations in fuel products of Taiwan range from $9.6 \mathrm{ng} \cdot \mathrm{g}^{-1}$ to $17.9 \mathrm{ng} \cdot \mathrm{g}^{-1}$ (unleaded gasoline) and $29.4 \mathrm{ng} \cdot \mathrm{g}^{-1}$ to $44.8 \mathrm{ng} \cdot \mathrm{g}^{-1}$ (diesel), below the national guideline value of $0.013 \mathrm{~g} / \mathrm{L}$ [12] (Table 2). After switching from leaded to unleaded gasoline (Figure 1), $\mathrm{Pb}$ in unleaded gasoline products (measured in ppb) is definitely not tetraethyl $\mathrm{Pb}$. However, trace amount of $\mathrm{Pb}$ in these products might have originated from the crude oil. Diesel has elevated $\mathrm{Pb}$ level than unleaded gasoline. And CPC's \#92 unleaded gasoline has the lowest $\mathrm{Pb}$ content, $9.6 \mathrm{ng} \cdot \mathrm{g}^{-1}$. 


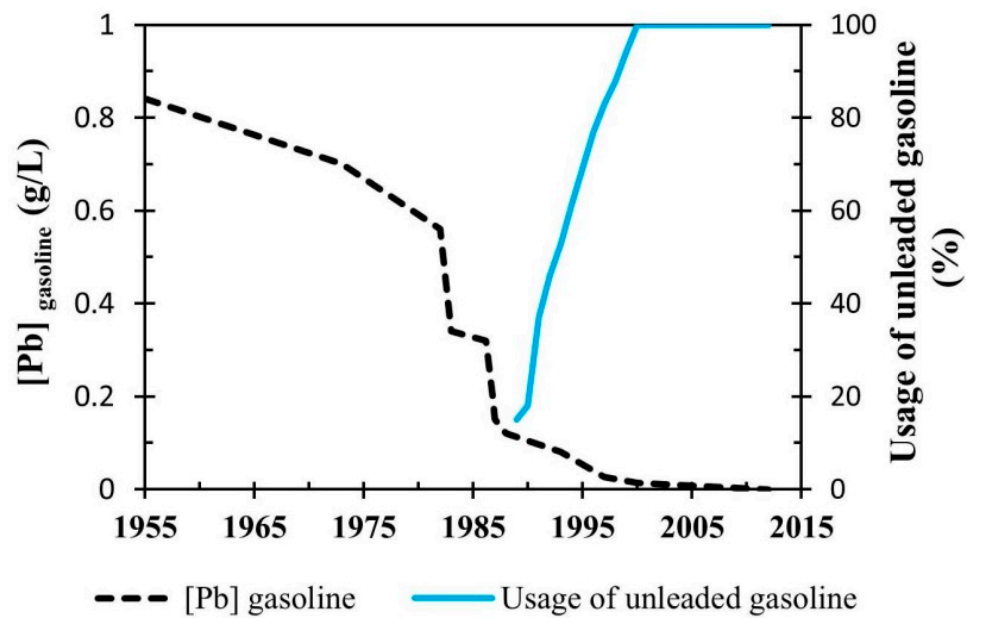

Figure 1. History of the use of petroleum fuels in Taiwan (data from [12]).

Table 2. Summary of $\mathrm{Pb}$ isotopic characteristics and level in Taiwan's fuel products (mean \pm 1 S.D., $\mathrm{n}=3$ ).

\begin{tabular}{|c|c|c|c|c|c|c|c|c|}
\hline $\mathrm{Br}$ & Product & ${ }^{208} \mathrm{~Pb} /{ }^{207} \mathrm{~Pb}$ & ${ }^{208} \mathrm{~Pb} /{ }^{206} \mathrm{~Pb}$ & ${ }^{206} \mathrm{~Pb} /{ }^{207} \mathrm{~Pb}$ & ${ }^{206} \mathrm{~Pb} /{ }^{204} \mathrm{~Pb}$ & ${ }^{207} \mathrm{~Pb} /{ }^{204} \mathrm{~Pb}$ & ${ }^{208} \mathrm{~Pb} /{ }^{204} \mathrm{~Pb}$ & {$[\mathrm{~Pb}]\left(\mathrm{ng} \cdot \mathrm{g}^{-1}\right)$} \\
\hline $\begin{array}{l}\text { Chinese } \\
\text { Petroleum }\end{array}$ & $\begin{array}{l}\text { \#92 unleaded } \\
\text { gasoline }\end{array}$ & $\begin{array}{c}2.422 \pm \\
0.002\end{array}$ & $\begin{array}{c}2.111 \pm \\
0.002\end{array}$ & $\begin{array}{c}1.147 \pm \\
0.002\end{array}$ & $\begin{array}{c}17.86 \pm \\
0.02\end{array}$ & $15.57 \pm 0.01$ & $37.71 \pm 0.02$ & \\
\hline \multirow{3}{*}{$\begin{array}{l}\text { Corporation, } \\
\text { Taiwan } \\
(\mathrm{CPC})\end{array}$} & $\begin{array}{l}\text { \#95 unleaded } \\
\text { gasoline }\end{array}$ & $\begin{array}{c}2.429 \pm \\
0.003\end{array}$ & $\begin{array}{c}2.110 \pm \\
0.005\end{array}$ & $\begin{array}{c}1.151 \pm \\
0.002\end{array}$ & $\begin{array}{c}17.94 \pm \\
0.02\end{array}$ & $\begin{array}{c}15.588 \pm \\
0.006\end{array}$ & 0.06 & 16.9 \\
\hline & $\begin{array}{l}\text { \#98 unleaded } \\
\text { gasoline }\end{array}$ & $\begin{array}{c}2.417 \pm \\
0.003 \\
\end{array}$ & $\begin{array}{c}2.107 \pm \\
0.004 \\
\end{array}$ & $\begin{array}{c}1.147 \pm \\
0.003 \\
\end{array}$ & $\begin{array}{c}17.87 \pm \\
0.05 \\
\end{array}$ & $\begin{array}{c}15.578 \pm \\
0.003 \\
\end{array}$ & $37.65=$ & $16.4 \pm 2.6$ \\
\hline & & $\begin{array}{c}2.431 \pm \\
0.004 \\
\end{array}$ & $\begin{array}{c}2.115 \pm \\
0.009 \\
\end{array}$ & $\begin{array}{c}1.149 \pm \\
0.007 \\
\end{array}$ & $\begin{array}{c}17.89 \pm \\
0.08 \\
\end{array}$ & $15.57 \pm 0.02$ & $37.84=$ & 75.2 \\
\hline $\begin{array}{l}\text { Formosa } \\
\text { Plastics }\end{array}$ & $\begin{array}{c}\text { \#92 unleaded } \\
\text { gasoline }\end{array}$ & $\begin{array}{c}2.4288 \pm \\
0.0009 \\
\end{array}$ & $\begin{array}{c}2.1204 \pm \\
0.0004 \\
\end{array}$ & $\begin{array}{c}1.1454 \pm \\
0.0004 \\
\end{array}$ & $\begin{array}{c}17.836 \pm \\
0.004 \\
\end{array}$ & $\begin{array}{c}15.571 \pm \\
0.007 \\
\end{array}$ & $\begin{array}{c}37.819 \pm \\
0.004 \\
\end{array}$ & 3.5 \\
\hline \multirow[t]{3}{*}{$\begin{array}{l}\text { Corporation } \\
\text { (FPC) }\end{array}$} & $\begin{array}{l}\text { \#95 unleaded } \\
\text { gasoline }\end{array}$ & $\begin{array}{c}2.425 \pm \\
0.001 \\
\end{array}$ & $\begin{array}{c}2.125 \pm \\
0.004 \\
\end{array}$ & $\begin{array}{c}1.141 \pm \\
0.002 \\
\end{array}$ & $\begin{array}{c}17.78 \pm \\
0.05 \\
\end{array}$ & $15.58 \pm 0.01$ & $37.79 \pm 0.04$ & $14.6 \pm 3.9$ \\
\hline & $\begin{array}{l}\text { \#98 unleaded } \\
\text { gasoline }\end{array}$ & $\begin{array}{c}2.4278 \pm \\
0.0009 \\
\end{array}$ & $\begin{array}{c}2.1192 \pm \\
0.0008 \\
\end{array}$ & $\begin{array}{c}1.1456 \pm \\
0.0002 \\
\end{array}$ & $\begin{array}{c}17.847 \pm \\
0.008 \\
\end{array}$ & $\begin{array}{c}15.579 \pm \\
0.006 \\
\end{array}$ & $\begin{array}{c}37.822 \pm \\
0.002 \\
\end{array}$ & $15.9 \pm 2.4$ \\
\hline & diesel & $\begin{array}{c}2.433 \pm \\
0.003 \\
\end{array}$ & $\begin{array}{c}2.119 \pm \\
0.005\end{array}$ & $\begin{array}{c}1.148 \pm \\
0.003 \\
\end{array}$ & $\begin{array}{c}17.89 \pm \\
0.05 \\
\end{array}$ & $\begin{array}{c}15.582 \pm \\
0.004 \\
\end{array}$ & $37.91 \pm 0.04$ & $29.4 \pm 22.4$ \\
\hline
\end{tabular}

\subsection{Lead Isotopic Ratios of Taiwan's Fuel Products}

Our unleaded gasoline and diesel samples contain $\mathrm{Pb}$ in parts per billion (ppb) levels, which were analyzed by high-precision $\mathrm{Pb}$ isotopic analysis. The results of $\mathrm{Pb}$ isotopic ratios for Taiwan's fuel products are given in Table 2 and in Figure 2. Monna et al. [7] pointed out that environmental scientists tend to use ${ }^{206} \mathrm{~Pb} /{ }^{207} \mathrm{~Pb}$ when conducting environmental forensics. With ${ }^{206} \mathrm{~Pb} /{ }^{207} \mathrm{~Pb}$ data, identification of gasoline as the dominant source of environmental $\mathrm{Pb}$ can be readily achieved [31]. Our measurements shows CPC's \#95 unleaded gasoline has the highest ${ }^{206} \mathrm{~Pb} /{ }^{207} \mathrm{~Pb}$ ratios, averaging $1.151(\mathrm{n}=3)$, while FPC's \#95 unleaded gasoline has the lowest mean of $1.141(\mathrm{n}=3)$.

While Monna et al. [7] applied ${ }^{206} \mathrm{~Pb} /{ }^{207} \mathrm{~Pb}$ versus ${ }^{208} \mathrm{~Pb} /{ }^{206} \mathrm{~Pb}$ diagrams and ${ }^{206} \mathrm{~Pb} /{ }^{207} \mathrm{~Pb}$ versus ${ }^{206} \mathrm{~Pb} /{ }^{204} \mathrm{~Pb}$ diagram in conducting European environmental forensics, the available $\mathrm{Pb}$ isotopic records 
for Taiwan (i.e., [17,20]) were just given in ${ }^{208} \mathrm{~Pb} /{ }^{207} \mathrm{~Pb}$ and ${ }^{206} \mathrm{~Pb} /{ }^{207} \mathrm{~Pb}$ ratios. Because ${ }^{204} \mathrm{~Pb}$ is not readily detected by ICP-Q-MS, many previous environmental studies do not present it, and we would lack interpretation on mixtures from more than two sources [31]. Therefore, we took ${ }^{208} \mathrm{~Pb} /{ }^{207} \mathrm{~Pb}$ and ${ }^{206} \mathrm{~Pb} /{ }^{207} \mathrm{~Pb}$ values for comparison with recent studies in the following discussion and presented all ${ }^{204} \mathrm{~Pb}$ ratios (Table 2) for further studies to refer.
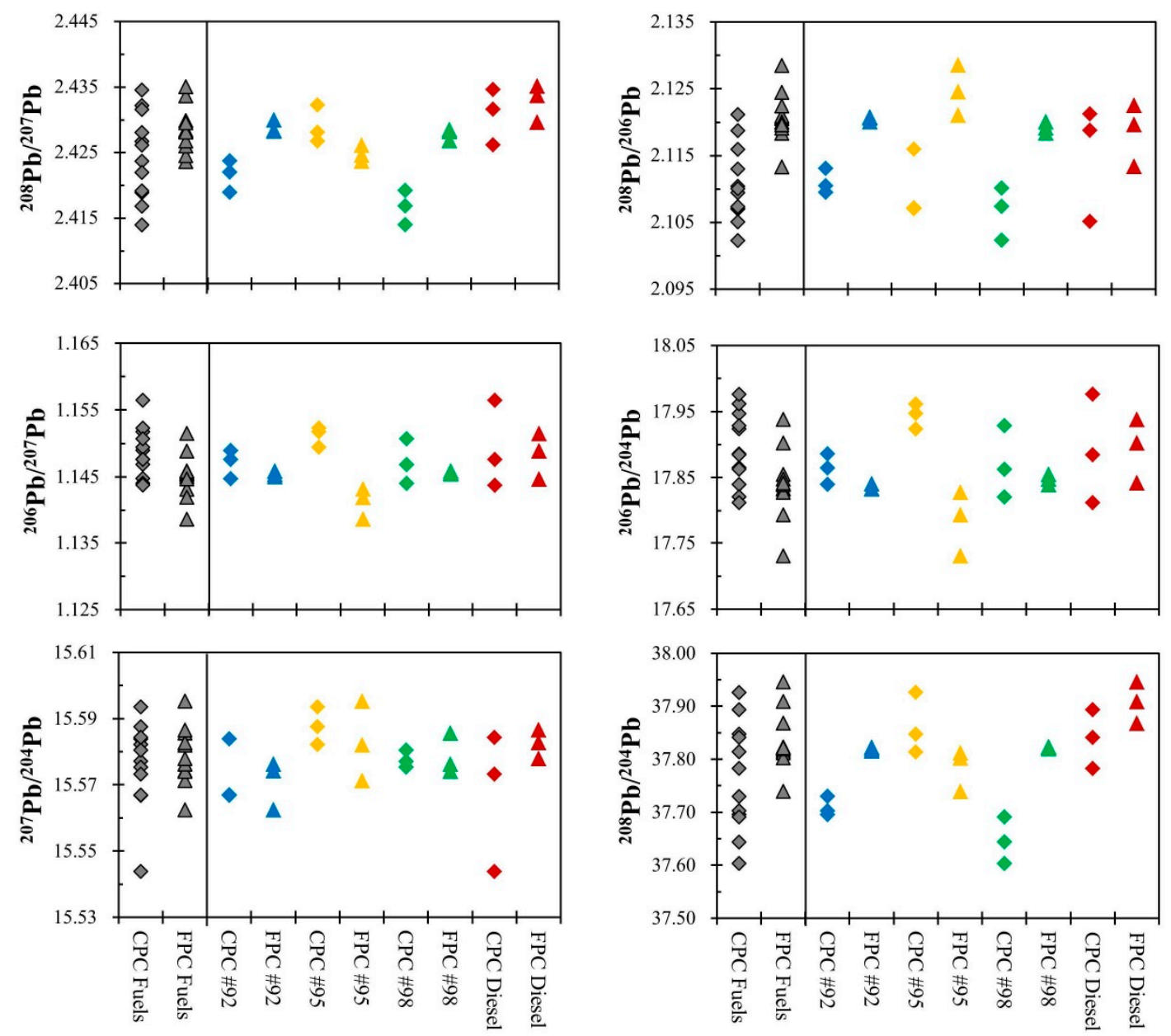

Figure 2. Lead isotopic ratios of Taiwan's fuel products collected from Chinese Petroleum Corporation, Taiwan (CPC) and Formosa Plastics Corporation (FPC). Besides, \#92, \#95 and \#98 represent unleaded gasoline with octane number 92, 95 and 98, respectively.

\section{Discussion}

\subsection{Comparison on Pb Isotopic Ratios of Worldwide Petroleum Fuels}

Petroleum fuel combustion has been considered as a major $\mathrm{Pb}$ input to the urban atmosphere, especially in the 1980s. But, rather than direct $\mathrm{Pb}$ isotopic ratios survey in fuels, most were obtained indirectly through calculating $\mathrm{Pb}$-ores data or sampling of aerosols. Moreover, available data in Asia are limited. In Table 3, we have compared our $\mathrm{Pb}$ isotopic ratios with those measured directly in other countries, including Austria [32], Finland [6], France [7], Germany [33], Hungary [32], Israel [5], Mexico [34], The Netherlands [32], Poland [32], Russia [8], Switzerland [11], UK [7,33,35], 
and USA $[21,36]$. Unleaded gasoline products were only obtained from Israel and USA, and the rest are all leaded products.

As observed in Table 3, Pb isotopic ratios vary in region, period and type, i.e., leaded or unleaded. Leaded gasoline products in Israel, France and UK have similar $\mathrm{Pb}$ isotopic compositions, which were characterized by the added alkyl-lead from a major producer in Europe [5,7]. The range of ${ }^{206} \mathrm{~Pb} /{ }^{207} \mathrm{~Pb}$ ratio is quite distinguishable among unleaded gasoline sold in Israel (1.11-1.15), Taiwan (1.14-1.15) and USA (1.19-1.24), although there is a little overlap in the former two. Besides, diesel in Taiwan has much higher (more radiogenic) ${ }^{206} \mathrm{~Pb} /{ }^{207} \mathrm{~Pb}$ ratios than diesel in Switzerland (Table 2). The variation spreads were due to the different crude oil types and fuel formulations. Since no $\mathrm{Pb}$-contained additive is added, lead isotopic ratios of unleaded gasoline products reflect $\mathrm{Pb}$ isotopic composition of crude oil.

Table 3. Summary of $\mathrm{Pb}$ isotopic characteristics in global petroleum products.

\begin{tabular}{|c|c|c|c|c|c|c|}
\hline Country & Item & Year & ${ }^{208} \mathrm{~Pb} /{ }^{206} \mathrm{~Pb}$ & ${ }^{206} \mathrm{~Pb} /{ }^{207} \mathrm{~Pb}$ & ${ }^{206} \mathrm{~Pb} /{ }^{204} \mathrm{~Pb}$ & Reference \\
\hline Austria & leaded gasoline & 1990 & NA & 1.111 & NA & Hopper et al. [32] \\
\hline Finland & gasoline & 1987 & NA & $1.122-1.159$ & $17.42-18.00$ & Keinonen [6] \\
\hline France & gasoline & 1995 & $2.172-2.198$ & $1.069-1.094$ & $16.56-17.07$ & Monna et al. [7] \\
\hline Germany & leaded gasoline & NA & NA & 1.10 & NA & Krause et al. [33] \\
\hline Hungary & leaded gasoline & 1990 & NA & 1.072 & NA & Hopper et al. [32] \\
\hline \multirow{3}{*}{ Israel } & 91 gasoline & 1995 & $2.148-2.158$ & $1.094-1.110$ & NA & \multirow{3}{*}{ Erel et al. [5] } \\
\hline & 96 gasoline & 1995 & $2.142-2.147$ & $1.108-1.119$ & NA & \\
\hline & unleaded gasoline & 1995 & $2.112-2.142$ & $1.108-1.146$ & NA & \\
\hline Mexico & leaded gasoline & 1988-1989 & $2.049-2.055$ & $1.202-1.204$ & $18.69-18.73$ & $\begin{array}{l}\text { Sañudo-Wilhelmy } \\
\text { and Flegal [34] }\end{array}$ \\
\hline Netherlands & leaded gasoline & 1990 & NA & 1.062 & NA & Hopper et al. [32] \\
\hline Poland & leaded gasoline & 1988 & NA & 1.174 & NA & Hopper et al. [32] \\
\hline Russia & leaded gasoline & NA & $2.117-2.129$ & $1.135-1.149$ & NA & Mukai et al. [8] \\
\hline \multirow{2}{*}{ Switzerland } & leaded petrol & 1996-1997 & $2.116-2.179$ & $1.075-1.358$ & $16.59-17.63$ & \multirow{2}{*}{$\begin{array}{l}\text { Chiaradia and } \\
\text { Cupelin [11] }\end{array}$} \\
\hline & diesel & 1997 & 2.146 & 1.110 & 17.29 & \\
\hline \multirow{3}{*}{ UK } & \multirow{3}{*}{ leaded gasoline } & 1989-1998 & NA & $1.056-1.098$ & NA & Farmer et al. [35] \\
\hline & & NA & NA & 1.07 & NA & Krause et al. [33] \\
\hline & & 1994 & $1.189-2.197$ & $1.059-1.079$ & $16.50-16.72$ & Monna et al. [7] \\
\hline \multirow[t]{2}{*}{ USA } & leaded gasoline & 1964 & NA & $1.115-1.160$ & $17.38-18.14$ & $\begin{array}{l}\text { Chow and } \\
\text { Johnstone [36] }\end{array}$ \\
\hline & unleaded gasoline & 1997-1999 & NA & $1.190-1.240$ & $18.40-19.50$ & Hurst [21] \\
\hline \multirow{2}{*}{ Taiwan } & unleaded gasoline & 2012 & $2.102-2.129$ & $1.139-1.152$ & $17.73-17.96$ & \multirow{2}{*}{ This study } \\
\hline & diesel & 2012 & $2.105-2.122$ & $1.144-1.157$ & $17.81-17.98$ & \\
\hline
\end{tabular}

NA: not mentioned.

\subsection{Estimation on Taiwanese Local Vehicle Emissions}

As depicted in Figure 2, fuel products available from the two major suppliers have significant different ${ }^{208} \mathrm{~Pb} /{ }^{206} \mathrm{~Pb}$ ( $p$-value $<0.001$, $\mathrm{t}$ test). \#95 unleaded gasoline was also found as the obvious distinctive product. The significant difference between the ${ }^{208} \mathrm{~Pb} /{ }^{206} \mathrm{~Pb}$ of petroleum fuel products from CPC and FPC has revealed a new indicator for further petroleum-related environmental forensics. 
Based on the number of service stations in Taipei, the market share of CPC and FPC were $75 \%$ $(\mathrm{n}=57)$ and $25 \%(\mathrm{n}=19)$, respectively [13]. Meanwhile, the sales volume of unleaded gasoline \#92, \#95, \#98, and diesel were $25 \%, 35 \%, 10 \%$, and $30 \%$, respectively. Based on the sales and market share, Taiwanese local vehicle emissions could be estimated as 2.427 for ${ }^{208} \mathrm{~Pb} /{ }^{207} \mathrm{~Pb}, 2.114$ for ${ }^{208} \mathrm{~Pb} /{ }^{206} \mathrm{~Pb}, 1.148$ for ${ }^{206} \mathrm{~Pb} /{ }^{207} \mathrm{~Pb}, 17.89$ for ${ }^{206} \mathrm{~Pb} /{ }^{204} \mathrm{~Pb}, 15.58$ for ${ }^{207} \mathrm{~Pb} /{ }^{204} \mathrm{~Pb}$, and 37.81 for ${ }^{208} \mathrm{~Pb} /{ }^{204} \mathrm{~Pb}$.

\subsection{Environmental forensic Application in Taipei City's Atmosphere}

Taipei city has an area of $271.8 \mathrm{~km}^{2}$ with a population of 2.6 million. In Taipei, the Rapid Transit System transports 1.6 million passengers per day in 2012, but there are 1.8 million motor vehicles in the city, and 1.6 million passengers use city buses per day. During the period before phasing out $\mathrm{Pb}$ from gasoline, atmospheric $\mathrm{Pb}$ concentrations in Taipei once reached $700 \pm 390 \mathrm{ng} / \mathrm{m}^{3}$ [15]. Airborne $\mathrm{Pb}$ levels recently decreased to less than $27 \pm 61 \mathrm{ng} / \mathrm{m}^{3}$ [17]. During a period from April 2003 to February $2004,{ }^{208} \mathrm{~Pb} /{ }^{207} \mathrm{~Pb}$ ratios of Taipei's aerosols ranged from 2.35 to 2.45 , and ${ }^{206} \mathrm{~Pb} /{ }^{207} \mathrm{~Pb}$ ratios from 1.12 to 1.17 [17].

Lead levels in the air and blood have significantly decreased in the cities, due to the phase-out of leaded gasoline $[3,18,19,37]$. Taipei is in a basin terrain with heavy traffic, so the traffic-related contribution cannot be excluded. According to our previous estimation, the ${ }^{208} \mathrm{~Pb} /{ }^{207} \mathrm{~Pb}$ and ${ }^{206} \mathrm{~Pb} /{ }^{207} \mathrm{~Pb}$ values of Taiwan's local vehicle exhaust were 2.427 and 1.148, respectively, which are close to that of Taipei's aerosols reported by Hsu et al. [17], but the isotopic fingerprints of Taipei's aerosols [17] and our estimated local vehicle exhaust or fuel products are not in a perfect match (Figure 3). The former with an extensive and seasonal variation in its isotopic characteristics implies that multiple $\mathrm{Pb}$ sources exist in Taipei.

As illustrated in Figure 3, our estimated Taiwanese local vehicle emissions and Taipei's aerosols in winter and spring times [17] have similar $\mathrm{Pb}$ isotopic ratios, while Taipei's aerosols in the spring also show a little overlap with aerosols in Beijing and Shanghai, China [10,38]. However, the above measurements are not performed in the same period. Aerosols exhibit $\mathrm{Pb}$ isotopic ratios from fuel combustion since the atmospheric dispersion condition is poor in the winter. Another $\mathrm{Pb}$ contributor that could affect Taiwan is the long-range transport of dust from China during the northeastern monsoon seasons from December to next May, especially in February, March and April [39].

Aerosols in the summer showed different isotopic patterns compared to our measurements on fuel products, which suggests that other main contributors might also exist. Resuspension of Pb-tainted urban soil, i.e., the contaminant remained from leaded gasoline consumption, could pose a threat on the current urban environment [37,40,41]. In an earlier study, Hsu et al. [17] collected and analyzed particulate matter accumulated on wall tile surface (PMT) from the main tunnels in downtown Taipei and assumed the $\mathrm{Pb}$ originated from the local vehicle emissions. However, their reported values, 2.405 for ${ }^{208} \mathrm{~Pb} /{ }^{207} \mathrm{~Pb}$ and 1.131 for ${ }^{206} \mathrm{~Pb} /{ }^{207} \mathrm{~Pb}$, were lower than ours. We suggest that the PMT samples should be explained as the combustion products of leaded gasoline coated on tunnel wall, which influence Taipei's aerosols in the summer and autumn seasons, consistent with Laidlaw's [37] finding. Lead from the past leaded gasoline continues to affect the current urban air through resuspension during dry seasons with high evapotranspiration rates [37]. Even though, urban traffic exhausts alone is insufficient to form the summer aerosol $\mathrm{Pb}$ isotopic characteristic.

Flegal et al. [42] have summarized the major sources of $\mathrm{Pb}$ contamination in China, including: (1) deposits from previous emissions of leaded gasoline, (2) previous and continuing emissions from 
fossil fuel combustion, (3) previous and continuing emissions from other industrial activities, and (4) previous and continuing additions of contaminated fertilizers, sewage, and untreated wastewater to agricultural fields. However, unlike China, coal combustion almost exclusively takes place in five thermal power plants in Taiwan [14] and the coals are mainly imported from Australia and Indonesia, which have a higher ${ }^{206} \mathrm{~Pb} /{ }^{207} \mathrm{~Pb}$ ratio of 1.21 and 1.18 , respectively [43]. Meanwhile, Taiwan also imports Australian $\mathrm{Pb}$ ores, which have low ${ }^{208} \mathrm{~Pb} /{ }^{207} \mathrm{~Pb}$ and ${ }^{206} \mathrm{~Pb} /{ }^{207} \mathrm{~Pb}$ values of 2.33 and 1.05 [44]. Therefore, the lowest ${ }^{206} \mathrm{~Pb} /{ }^{207} \mathrm{~Pb}$ signature found in the summer is believed to have come from pervious and current urban traffic exhausts mixed with southwest outflow of Taiwanese industrial processes and coal-powered electricity generators. To sum up, local vehicle fuel combustion and industrial activities, as well as the long-range dust transport from China in the specific seasons have dominated isotopic characteristics of aerosols in Taipei metropolis (Figure 3).

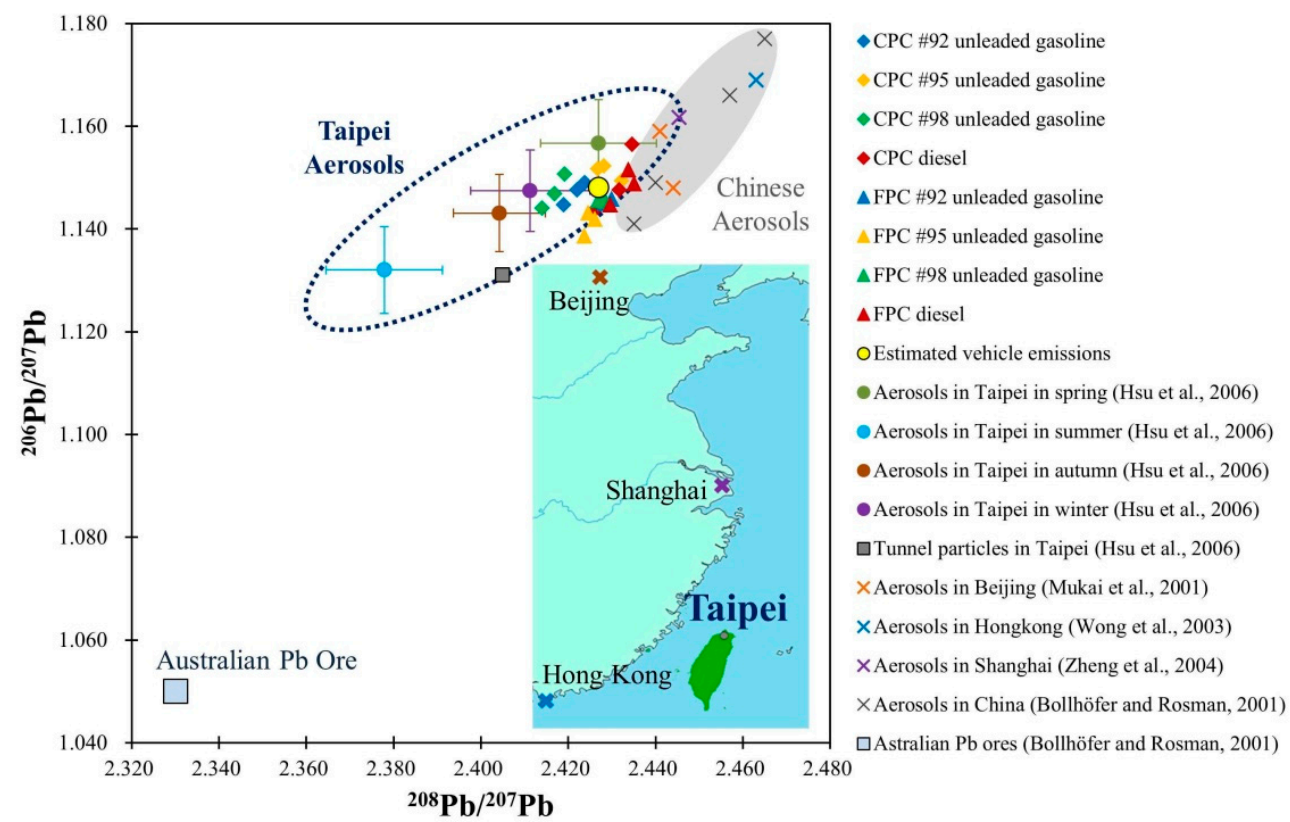

Figure 3. Scatter plot of ${ }^{208} \mathrm{~Pb} /{ }^{207} \mathrm{~Pb}$ versus ${ }^{206} \mathrm{~Pb} /{ }^{207} \mathrm{~Pb}$ for fuel products, estimated local vehicle emissions (the yellow circle), and particulate matter accumulated on wall tile surface from the main tunnels (PMT samples) [17] (the dark gray square) and seasonal aerosols collected in Taipei (drawn as the dotted ellipse; refer to Hsu et al. [17] for details data). The gray ellipse area represents Chinese aerosols [10,38,44,45]. Lead isotopic feature of Australian $\mathrm{Pb}$ ore [44], as the major import into Taiwan for industry, is also shown.

\subsection{Environmental Forensic Application in Pengjia Islet's Atmosphere}

Another available $\mathrm{Pb}$ isotopic record in Taiwan concerns Pengjia Islet's airborne particulate material,

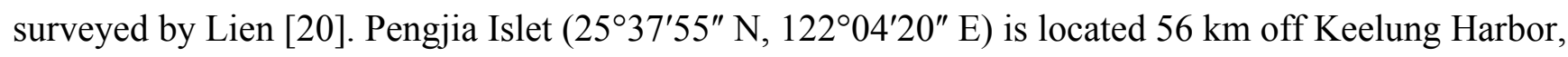
in northern Taiwan. With an area of 114 hectares, the islet has a highest altitude of $165 \mathrm{~m}$, gradually decreasing from east to west. Due to the fierce wind its vegetation consists primarily of grasses. Only a few people, less than 40, are stationed on the islet, such as the staff of the lighthouse, weather station and 
some soldiers. The islet is administered by the Keelung Municipal Government. In addition, its aerosols show seasonal differences in $\mathrm{Pb}$ isotopic ratios during 1997 to 2000 [20].

Mukai et al. [8] suggested that the $\mathrm{Pb}$ isotopic signatures of aerosols are a good indicator of long-range transport of air pollutants in Asia, with a demonstration in Oki Islands, Japan. Figure 4 illustrates ${ }^{208} \mathrm{~Pb} /{ }^{207} \mathrm{~Pb}$ versus ${ }^{206} \mathrm{~Pb} /{ }^{207} \mathrm{~Pb}$ plot of aerosols in Pengjia Islet [20] and its possible $\mathrm{Pb}$ sources. In addition to our measurements, we also examined aerosol records in Beijing, Hong Kong and Shanghai, China $[10,38,44,45]$, and Oki Islands, Japan [8]. Because of its clean environment and small population, we assumed that the local $\mathrm{Pb}$ contribution is negligible. As displayed in Figure 4, $\mathrm{Pb}$ isotopic ratios of aerosols in the summer show distinctive characteristics from those of other seasons in Pengjia Islet but similar to the isotopic ratios of our Taiwanese local vehicle emissions. Pb isotopic compositions of aerosols in Pengjia Islet overlap and resemble the pattern of Chinese aerosols [10,38] in seasons other than summer, which might be caused by different seasonal wind directions. Fuels' $\mathrm{Pb}$ isotopic ratios and historical $\mathrm{Pb}$ isotopic data in Pengjia Islet suggest that the $\mathrm{Pb}$ in aerosols was more likely from fuel combustion in Taiwan in the summer months, when the southwest monsoon prevails, while in the northeast monsoon season, the long-range transport of $\mathrm{Pb}$-rich aerosols from China becomes dominant (Figure 4).

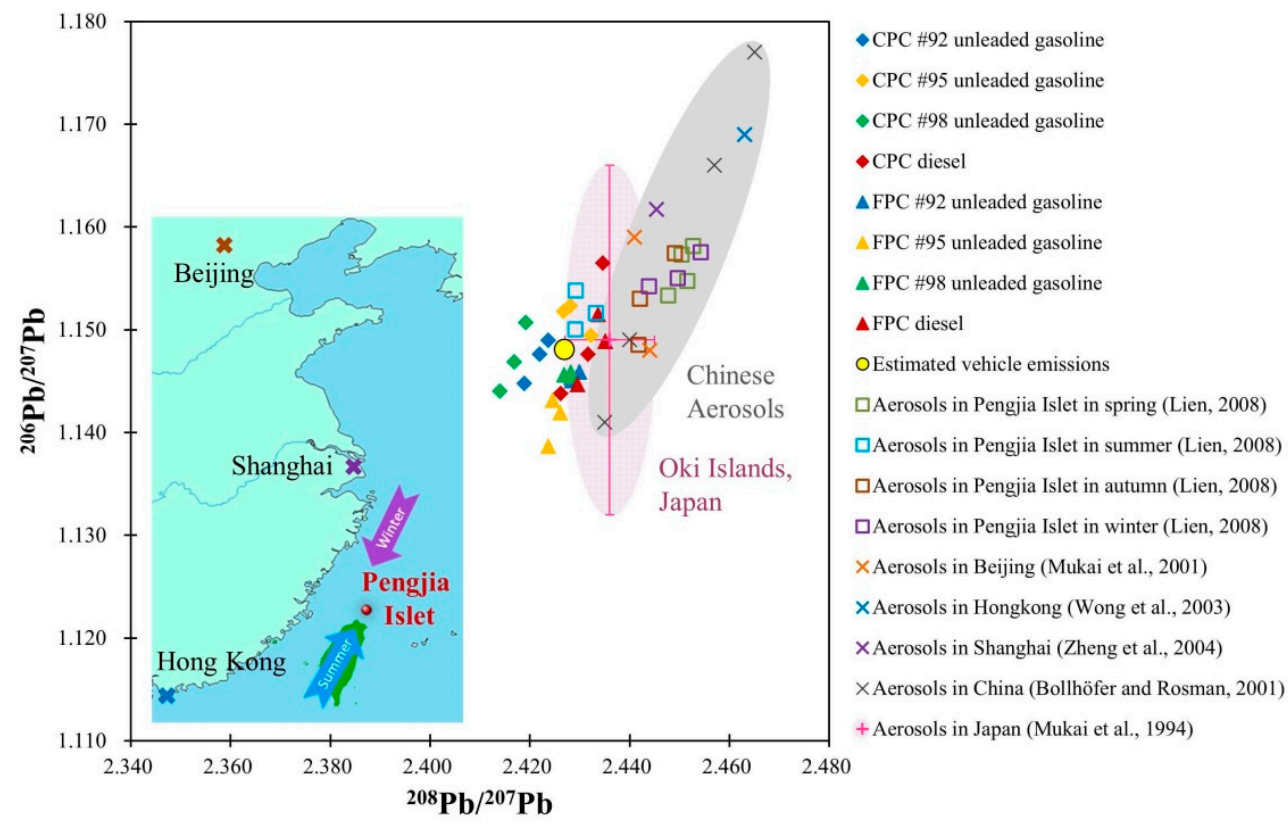

Figure 4. Scatter plot of ${ }^{208} \mathrm{~Pb} /{ }^{207} \mathrm{~Pb}$ versus ${ }^{206} \mathrm{~Pb} /{ }^{207} \mathrm{~Pb}$ for fuel products, estimated Taiwanese vehicle emissions (the yellow circle), together with the seasonal aerosols collected in Pengjia Islet by Lien [20], drawn as blank squares. The gray ellipse area represents Chinese aerosols [10,38,44,45]. In addition, aerosol records in Oki Islands, Japan [8] recalculated and summarized are also shown as a pink ellipse.

\subsection{Implication and Limitation}

Because Taiwan imports most of its crude oil, $\mathrm{Pb}$ isotopic ratios in Taiwan's petroleum products might change with the supply sources. However, gasoline and diesel products from the two local major suppliers have distinctive ${ }^{208} \mathrm{~Pb} /{ }^{206} \mathrm{~Pb}$ values, which can help identify the sources of petroleum fuels 
accidentally released into the environment, and trace the liability in oil spills. Tracing anthropogenic air pollution can be achieved by comparing our measurements with previous atmospheric studies in Taiwan and neighboring countries. For example, the deciphering $\mathrm{Pb}$ isotopic ratios of atmospheric particles in Pengjia Islet may be useful to study the impact of long-range dust transport from China on northern Taiwan.

Lead isotopic ratios show greater seasonal variations in Taipei city (ICP-Q-MS data [17]) than in Pengjia Islet (MC-ICP-MS data without ${ }^{204} \mathrm{~Pb}$ ratios [20]). This implies that in addition to local fuel combustion (according to our own MC-ICP-MS data), multiple Pb contributors exist in metropolitan Taipei. A binary mixing model [7,17] could not be applied in this study to calculate the relative contribution due to the complex constituents and poor linearity. Coal and $\mathrm{Pb}$ ores for electricity and industry are mainly imported from Australia. According to the isotopic characteristics, air quality in Taipei metropolis is affected by local fuel combustion, resuspended solid particles (previously assumed as PMT samples), southwest airflow from electric power plants, as well as dust from China through the northeastern monsoon. Among those contributors, resuspended solid particles and air pollutants from China mainland pose pollution threats and merit further investigation.

Laidlaw et al. [37], Harris and Davidson [40] and Zahran et al. [41] have highlighted the role of resuspended $\mathrm{Pb}$-tainted urban soil, which had been contaminated by the past leaded gasoline emissions, as a dominant source of atmospheric $\mathrm{Pb}$ in cities. During dry seasons when evapotranspiration potential is high and soil moisture is low, $\mathrm{Pb}$ from the past contaminated soil continues to affect the current urban air [37]. The more $\mathrm{Pb}$-tainted soil is resuspended, the higher the $\mathrm{Pb}$ level that is monitored in the air $[37,41]$. Furthermore, the legacy of $\mathrm{Pb}$ in urban atmospheres cannot hide under the novel isotopic finger-printing technique. After the phase-out of leaded gasoline, other contributors to air pollution have been uncovered by distinctive $\mathrm{Pb}$ isotopic signatures, and even the isotopic ratios of unleaded fuel products can be used for tracking. Environmental $\mathrm{Pb}$ and its isotopic characteristics will be shown in human teeth and bones as a record on $\mathrm{Pb}$ exposure as a georeferencing means as suggested by Kamenov and Gulson [46]. Besides petroleum fuel combustion in metropolis, $\mathrm{Pb}$ isotopic fingerprinting could identify and perhaps quantify contributions from complex domestic sources and cross-border transport of air pollutants. Through improved analytical protocols and instruments [23-30], reliable ${ }^{204} \mathrm{~Pb}$ (non-radiogenic but not readily analyzed in the past) data obtained could help to characterize and differentiate mixed multiple sources [31]. Further investigations on high-precision $\mathrm{Pb}$ isotopic ratios of $\mathrm{Pb}$ pollution sources and other related media are merited.

\section{Conclusions}

The following conclusions are based on this study and the analysis of related investigations:

(1) Urban aerosol $\mathrm{Pb}$ content has decreased by almost one order of magnitude compared to levels in 1991 when leaded fuels were still in use.

(2) Precise $\mathrm{Pb}$ isotopic ratios of unleaded petroleum fuels in Taipei, Taiwan were determined and thoroughly analyzed, which is the first such attempt in East Asia. Our results show that lead isotopic characterization is applicable as a "fingerprinting" tool for tracing $\mathrm{Pb}$ pollution sources. The distinction between the products of the two oil companies is statistically significant ( $p$-value $<0.001, \mathrm{t}$ test) in their individual ${ }^{208} \mathrm{~Pb} /{ }^{206} \mathrm{~Pb}$ ratios. Lead isotopic ratios of vehicle 
exhaust $\left({ }^{208} \mathrm{~Pb} /{ }^{207} \mathrm{~Pb}: 2.427,{ }^{206} \mathrm{~Pb} /{ }^{207} \mathrm{~Pb}\right.$ : 1.148 , as estimated from petroleum fuels) overlap with the reported urban aerosol data.

(3) Fuel products and Taipei's aerosols show similar isotopic signatures in the winter when poor atmospheric dispersion conditions persist. This suggests that local unleaded fuel combustion was a $\mathrm{Pb}$ contributor to the metropolitan air. Greater seasonal variation of $\mathrm{Pb}$ isotopic ratios in spring and summer time implies that other sources exist in addition to fuel combustion. Considering the climate conditions, Asian dust storms (in spring), resuspended solid or soil particles, and the southwest airflow of anthropogenic activities (in summertime) might be the key $\mathrm{Pb}$ contributors in air during the recent past.

\section{Acknowledgments}

This study was financially supported by Environmental Protection Administration, R.O.C. (Taiwan EPA). We also thank financial supports by Taiwan ROC MOST (102-2116-M-002-016 and 103-2119-M-002-022) and National Taiwan University (101R7625). The authors acknowledge the two anonymous reviewers, Howard W. Mielke (Tulane University School of Medicine, USA), Shih-Chieh Hsu (Research Center for Environmental Changes, Academic Sinica) and Long-Chuan Wu (Chinese Petroleum Corporation, Taiwan) for their critical and constructive comments. We also appreciate Dr. Chih-Tse Wang (MWH Americas Inc., Taiwan Branch) and colleagues of AELab and HSIPEC (National Taiwan University) for research assistance.

\section{Author Contributions}

Pei-Hsuan Yao performed data collection, analysis and interpretation, and wrote the manuscript; Guey-Shin Shyu contributed to study design and drafting the paper; Ying-Fang Chang contributed to acquisition of data; Yu-Chen Chou and Chuan-Chou Shen contributed to data quality assurance procedures; Chi-Su Chou contributed to critical revision of the manuscript; Tsun-Kuo Chang made substantial contributions to conception, study design and interpretation of data, and provided critical revision of the manuscript. All authors contributed to the manuscript and approved the final version.

\section{Conflicts of Interest}

The authors declare no conflict of interest.

\section{References}

1. Kabata-Pendias, A.; Mukherjee, A.B. Trace Elements from Soils to Human; Spriner: New York, NY, USA, 2007; pp. 368-369.

2. Patterson, C.C. An alternative perspective: Lead pollution in the human environment: origin, extent, and significance. In Lead in the Human Environment; Committee on Lead in the Human Environment, Environmental Studies Board Commission on Natural Resources, National Research Council, National Academy of Sciences: Washington, DC, USA, 1980; pp. 265-274.

3. Mielke, H.W.; Zahran, S. The urban rise and fall of air lead $(\mathrm{Pb})$ and the latent surge and retreat of societal violence. Environ. Int. 2012, 43, 48-55. 
4. Nriagu, J.O. The rise and fall of leaded gasoline. Sci. Total Environ. 1990, 92, 13-28.

5. Erel, Y.; Veron, A.; Halicz, L. Tracing the transport of anthropogenic lead in the atmosphere and in soils using isotopic ratios. Geochim. Cosmochim. Acta 1997, 61, 4495-4505.

6. Keinonen, M. The isotopic composition of lead in man and the environment in Finland 1966-1987: Isotope ratios of lead as indicators of pollutant source. Sci. Total Environ. 1990, 113, 251-268.

7. Monna, F.; Lancelot, J.; Croudace, I.W.; Cundy, A.B.; Lewis, J.T. Lead isotopic composition of airborne material from France and the Southern U.K. implications for Pb pollution sources in urban areas. Environ. Sci. Technol. 1997, 31, 2277-2286.

8. Mukai, H.; Tanaka, A.; Fujii, T.; Nakao, M. Lead isotope ratios of airborne particulate matter as tracers of long-range transport of air pollutants around Japan. J. Geophys. Res. 1994, 99, 3717-3726.

9. Widory, D.; Liu, X.; Dong, S. Isotopes as tracers of sources of lead and strontium in aerosols (TSP \& PM2.5) in Beijing. Atmos. Environ. 2010, 44, 3679-3687.

10. Zheng, J.; Tan, M.G.; Shibata, Y.; Tanaka, A.; Li, Y.; Zhang, G.L.; Zhang, Y.M.; Shan, Z. Characteristics of lead isotope ratios and elemental concentrations in $\mathrm{PM}_{10}$ fraction of airborne particulate matter in Shanghai after the phase-out of leaded gasoline. Atmos. Environ. 2004, 38, 1191-1200.

11. Chiaradia, M.; Cupelin, F. Behaviour of airborne lead and temporal variations of its source effects in Geneva (Switzerland): Comparison of anthropogenic versus natural processes. Atmos. Environ. 2000, 34, 959-971.

12. Taiwan EPA. Mobile Source Control. Available online: https://mobile.epa.gov.tw/ oilimprovement_1.aspx (accessed on 7 April 2015).

13. Taiwan Bureau of Energy (BOE). Petroleum Price Information Management and Analysis System. Available online: http://www.moeaboe.gov.tw/oil102/ (accessed on 7 April 2015).

14. Taiwan BOE. Energy Statistics Handbook; Bureau of Energy, Ministry of Economic Affairs: Taipei, Taiwan, 2013.

15. Mao, I.F.; Chen, M.L. Airborne lead pollution in metropolitan Taipei (Republic of China). Water Air Soil Pollut. 1996, 91, 375-382.

16. Hsu, S.-C.; Liu, S.-C.; Jeng, W.-L.; Lin, F.-J.; Huang, Y.-T.; Lung, S.-C.C.; Liu, T.-H.; Tu, J.-Y. Variations of $\mathrm{Cd} / \mathrm{Pb}$ and $\mathrm{Zn} / \mathrm{Pb}$ ratios in Taipei aerosols reflecting long-range transport or local pollution emissions. Sci. Total Environ. 2005, 347, 111-121.

17. Hsu, S.-C.; Liu, S.-C.; Jeng, W.-L.; Chou, C.C.-K.; Hsu, R.-T.; Huang, Y.-T.; Chen, Y.-W. Lead isotope ratios in ambient aerosols from Taipei, Taiwan: Identifying long-range transport of airborne Pb from the Yangtze Delta. Atmos. Environ. 2006, 40, 5393-5404.

18. Hwang, Y.-H.; Ko, Y.; Chiang, C.-D.; Hsu, S.-P.; Lee, Y.-H.; Yu, C.-H.; Chiou, C.-H.; Wang, J.-D.; Chuang, H.-Y. Transition of cord blood lead level, 1985-2002, in the Taipei area and its determinants after the cease of leaded gasoline use. Environ. Res. 2004, 96, 274-282.

19. Lin, Y.-Y.; Guo, Y.-L.L.; Chen, P.-C.; Liu, J.-H.; Wu, H.-G.; Hwang, Y.-H. Associations between petrol-station density and manganese and lead in the cord blood of newborns living in Taiwan. Environ. Res. 2011, 111, 260-265. 
20. Lien, M.Y. Tracing Sources Variation of Lead in Aerosols Collected from the Peng Chia Yu: Chemical Compositions and $\mathrm{Pb}$ Isotopess. Master's Thesis, National Cheng-Kung University: Tainan, Taiwan, 2008.

21. Hurst, R.W. Lead isotopes as age-sensitive, genetic markers in hydrocarbons: 2. Kerogens, crude oils, and unleaded gasoline. Environ. Geosci. 2002, 9, 1-7.

22. Shen, C.-C.; Wu, C.-C.; Cheng, H.; Edwards, R.L.; Hsieh, Y.-T.; Gallet, S.; Chang, C.-C.; Li, T.-Y.; Lam, D.D.; Kano, A.; et al. High-precision and high-resolution carbonate ${ }^{230} \mathrm{Th}$ dating by MC-ICP-MS with SEM protocols. Geochim. Cosmochim. Acta 2012, 99, 71-86.

23. Gale, N.H. A new method for extracting and purifying lead from difficult matrices for isotopic analysis. Anal. Chim. Acta 1996, 332, 15-21.

24. Baker, J.; Peate, D.; Waight, T.; Meyzen, C. Pb isotopic analysis of standards and samples using a ${ }^{207} \mathrm{~Pb}-{ }^{204} \mathrm{~Pb}$ double spike and thallium to correct for mass bias with a double-focusing MC-ICP-MS. Chem. Geol. 2004, 211, 275-303.

25. Kamenov, G.D.; Mueller, P.A.; Perfit, M.R. Optimization of mixed $\mathrm{Pb}-\mathrm{Tl}$ solutions for high precision isotopic analyses by MC-ICP-MS. J. Anal. Atom. Spectrom. 2004, 19, 1262-1267.

26. Weiss, D.J.; Kober, B.; Dolgopolova, A.; Gallagher, K.; Spiro, B.; Le Roux, G.; Mason, T.F.D.; Kylander, M.; Coles, B.J. Accurate and precise $\mathrm{Pb}$ isotope ratio measurements in environmental samples by MC-ICP-MS. Int. J. Mass Spectrom. 2004, 232, 205-215.

27. White, W.M.; Albarède, F.; Télouk, P. High-precision analysis of $\mathrm{Pb}$ isotope ratios by multi-collector ICP-MS. Chem. Geol. 2000, 167, 257-270.

28. Thirlwall, M.F. Multicollector ICP-MS analysis of $\mathrm{Pb}$ isotopes using a ${ }^{207} \mathrm{~Pb}^{204} \mathrm{~Pb}$ double spike demonstrates up to $400 \mathrm{ppm} / \mathrm{amu}$ systematic errors in Tl-normalization. Chem. Geol. 2002, 184, 255-279.

29. Galer, S.J.G.; Abouchami, W. Practical application of lead triple spiking for correction of instrumental mass discrimination. Min. Mag. 1998, 62A, 491-492.

30. Thirlwall, M.F. Inter-laboratory and other errors in $\mathrm{Pb}$ isotope analyses investigated using a ${ }^{207} \mathrm{~Pb}^{204} \mathrm{~Pb}$ double spike. Chem. Geol. 2000, 163, 299-322.

31. Ellam, R.M. The graphical presentation of lead isotope data for environmental source apportionment. Sci. Total Environ. 2010, 408, 3490-3492.

32. Hopper, J.F.; Ross, H.B.; Sturges, W.T.; Barrie, L.A. Regional source discrimination of atmospheric aerosols in Europe using the isotopic composition of lead. Tellus 1991, 43B, 45-60.

33. Krause, P.; Kriews, M.; Dannecker, W.; Garbe-Schönberg, C.-D.; Kersten, M. Determination of ${ }^{206 / 207} \mathrm{~Pb}$ isotope ratios by ICP-MS in particulate matter from the North Sea environment. Fresen. J. Anal. Chem. 1993, 347, 324-329.

34. Sañudo-Wilhelmy, S.A.; Flegal, A.R. Temporal variations in lead concentrations and isotopic composition in the Southern California Bight. Geochim. Cosmochim. Acta 1994, 58, 3315-3320.

35. Farmer, J.G.; Eades, L.J.; Graham, M.C.; Bacon, J.R. The changing nature of the ${ }^{206} \mathrm{~Pb} /{ }^{207} \mathrm{~Pb}$ isotopic ratio of lead in rainwater, atmospheric particulates, pine needles and leaded petrol in Scotland, 1982-1998. J. Environ. Monit. 2000, 2, 49-57.

36. Chow, T.J.; Johnstone, M.S. Lead isotopes in gasoline and aerosols of Los Angeles basin, California. Science 1965, 147, 502-503. 
37. Laidlaw, M.A.S.; Zahran, S.; Mielke, H.W.; Taylor, M.P.; Filippelli, G.M. Re-suspension of lead contaminated urban soil as a dominant source of atmospheric lead in Birmingham, Chicago, Detroit and Pittsburgh, USA. Atmos. Environ. 2012, 49, 302-310.

38. Mukai, H.; Tanaka, A.; Fujii, T.; Zeng, Y.Q.; Hong, Y.T.; Tang, J.; Guo, S.; Xue, H.S.; Sun, Z.L.; Zhou, J.T.; et al. Regional characteristics of sulfur and lead isotope ratios in the atmosphere at several Chinese urban sites. Environ. Sci. Technol. 2001, 35, 1064-1071.

39. Taiwan EPA. The Dust Storm. Available online: http://dust.epa.gov.tw/dust/tw/default.aspx (accessed on 7 April 2015).

40. Harris, A.R.; Davidson, C.I. The role of resuspended soil in lead flows in the California South Coast Air Basin. Environ. Sci. Technol. 2005, 39, 7410-7415.

41. Zahran, S.; Laidlaw, M.A.S.; McElmurry, S.P.; Filippelli, G.M.; Taylor, M. Linking source and effect: Resuspended soil lead, air lead, and children's blood lead levels in Detroit, Michigan. Environ. Sci. Technol. 2013, 47, 2839-2845.

42. Flegal, A.R.; Gallon, C.; Ganguli, P.M.; Conaway, C.H. All the lead in China. Critical Reviews in Environ. Sci. Technol. 2013, 43, 1869-1944.

43. Díaz-Somoano, M.; Kylander, M.E.; López-Antón, M.A.; Suárez-Ruiz, I.; Martínez-Tarazona, M.R.; Ferrat, M.; Kober, B.; Weiss, D.J. Stable lead isotope compositions in selected coals from around the world and implications for present day aerosol source tracing. Environ. Sci. Technol. 2009, 43, 1078-1085.

44. Bollhöfer, A.; Rosman, K.J.R. Isotopic source signatures for atmospheric lead: The northern hemisphere. Geochim. Cosmochim. Acta 2001, 65, 1727-1740.

45. Wong, C.S.C.; Li, X.D.; Zhang, G.; Qi, S.H.; Peng, X.Z. Atmospheric deposition of heavy metals in the Pearl River Delta, China. Atmos. Environ. 2003, 37, 767-776.

46. Kamenov, G.D.; Gulson, B.L. The Pb isotopic record of historical to modern human lead exposure. Sci. Total Environ. 2014, 490, 861-870.

(C) 2015 by the authors; licensee MDPI, Basel, Switzerland. This article is an open access article distributed under the terms and conditions of the Creative Commons Attribution license (http://creativecommons.org/licenses/by/4.0/). 